\title{
The cold water mass along the southeast and east coasts of Korea in 2016-2017
}

\author{
Hyo-Sang Choo \\ Department of Ocean Integrated Science, Chonnam National University, Yeosu 59626, Korea
}

\begin{abstract}
The spatial and temporal behaviors and fluctuations of the cold water that appeared in the South East Sea and the East Sea coast from 2016 to 2017 were investigated. The water temperature drop was large in the east coast from April to June and the southeast coast from July to September, and the temperature drop period was longer in the southeast coast. The water temperature fluctuated sensitively to the wind direction, and it gradually decreased in the southwest wind but rose as if jumping in the northeast wind. Wind stress and surface water temperature had an inverse correlation, which was larger in Bukhang-ldukseo, and decreased toward the north of Guryongpo. The cold water appeared mainly in Geojedo-Pohang after 1 to 2 days when the southwest wind was strong, but when the wind became weak, it shrank to the Idukseo (Ulgi-Gampo) and extended into the open sea in a tongue shape. Cold water was distributed only in Samcheok-Toseong in mid-May, Idukseo-Guryongpo and Hupo-Jukbyeon-Samcheok from late May to mid-July, and Bukhang-ldukseo in August-September. The intensity of cold water was greatest in mid-August, and the center of cold water descended from the east coast to the southeast coast from spring to summer. The water temperature fluctuation was dominant at the periods of $1 \mathrm{~d}$ and 7-21 d. In wavelet spectrum analysis of water temperature and wind, wind speed increase-water temperature decrease showed phase difference of $12 \mathrm{~h}$ in $2 \mathrm{~d}, 18 \mathrm{~h}$ in $3 \mathrm{~d}, 1.5 \mathrm{~d}$ in $4-8 \mathrm{~d}$, and 2-3 d in 8-24 d period. The correlation between the two parameters was large in Geojedo and Namhang, Bukhang-ldukseo, Guryongpo-Jukbyeon, and Samcheok-Toseong. Monitoring stations with high correlation in all periods were generally parallel to the monsoon direction.
\end{abstract}

Keywords: Southeast and East coasts of Korea, Cold water, Wind stress, Wavelet spectrum, Dominant fluctuation

\section{Introduction}

The decrease in the temperature of surface water due to coastal upwelling caused by monsoons usually occurs on the southeast coast of Korea during spring and summer. The occurrence of cold water mass and its origin has been mainly investigated based on water temperature distributions (Lee \& Na, 1985; Lee et al., 1998; Suh et al., 2001), satellite image data (Kim et al., 2008; Suh, 2001), and numerical experiments (Kim \& Kim, 2008; Seung, 1984) around the Ulgi-Gampo sea area (An,

\footnotetext{
Received: Mar 29, 2021 Revised: Apr 29, 2021 Accepted: Jun 28, 2021

${ }^{*}$ Corresponding author: Hyo-Sang Choo

Department of Ocean Integrated Science, Chonnam National University, Yeosu 59626, Korea

Tel: +82-61-659-7144, Fax: +82-61-659-7149, E-mail: choo@jnu.ac.kr
}

This is an Open Access article distributed under the terms of the Creative Commons Attribution Non-Commercial License (http://creativecommons.org/licenses/by$\mathrm{nc} / 4.0 /$ ) which permits unrestricted non-commercial use, distribution, and reproduction in any medium, provided the original work is properly cited.

Copyright $\odot 2021$ The Korean Society of Fisheries and Aquatic Science 
1974; Byun, 1989; Lee, 1983). During spring and summer, the low-temperature seawater in the middle and lower layers (i.e., $5{ }^{\circ} \mathrm{C}$ lower than the surface water temperature at a minimum) on the coast of the southeast sea rises to the ocean surface relative to the winds blowing parallel to the coast (National Institute of Fisheries Science [NIFS] , 1997; 1998). The detailed investigation of water temperature drop along the coast of the southeast sea of Korea has indicated that the these cold water masses emerge either because of the cold water current in North Korea (Kim \& Kim, 1983) or the coastal upwelling caused by the southwest monsoon (Kim \& Kim, 2008; Seung, 1984) and the increase in isotherm caused by the submarine topography (baroclinic tilt) (Lee \& Na, 1985). The main cause of the emergence of cold water masses were also investigated by the following studies. The southwestern winds causing the upwelling effect continuously blow in the abovementioned sea areas for more than $3 \mathrm{~d}$ in summer (Choo, 2016; Lee, 1983; Lee et al., 2003). The advection of the Tsushima current on the coast and the interaction with the wind is caused by the submarine topography and potential vortices generated (Lee \& Na, 1985; Lee et al., 1998). The relationship between the marine structure and minimum wind impulse was determined by Byun (1989). The experimental studies of Byun (1989), Kim \& Kim (2008), and Seung (1984) also showed that the wind-induced Ekman transport, coastline structure, and seabed topography were related to cold water surge along the southeast coast of Korea; these factors were compared with observed data.

By contrast, based on the results reported in the aforementioned studies, in which wind was considered the main factor causing the cold water surge, it is probable that the cold water mass emerging on the coast is upwelled by the winds, particularly the southwest winds blowing with an average speed of $3 \mathrm{~m} / \mathrm{s}$ consecutively for $7 \mathrm{~d}$ (Seung, 1984), southwest winds blowing with an average speed of $4 \mathrm{~m} / \mathrm{s}$ consecutively for $3 \mathrm{~d}$ (Lee, 1983), or a transient southwest wind blowing for several days. In summer, strong winds blowing with a speed of approximately $10 \mathrm{~m} / \mathrm{s}$ can cause cold water to emerge on the surface (Byun, 1989). In addition, Choo (2016) demonstrated that the coastal upwelling phenomenon reacted sensitively to the south-southwest wind fluctuations over a period of 2-6 d and the drop in water temperature had a phase difference of approximately 15-18 h, 2-3 d, and 24-27 h over wind periods of $4 \mathrm{~d}, 36 \mathrm{~h}$, and $6 \mathrm{~d}$, respectively.

The present study analyzed the temporal and spatial fluctuation patterns, periods, and coherence of the cold water mass emerging in the coastal area of the 17 monitoring stations of the weather buoy, lighthouse, and coastal wave buoy from southeastern Geojedo to northeastern Toseong of Korea. The time series data of surface water temperature, wind direction, speed, and air temperature monitored every hour from 2016 to 2017 were analyzed. The distribution patterns of the cold water mass with short-term horizontal spatial fluctuations were also investigated using the data from satellite remote sensing and vertical water temperature data measured along ocean observation lines. In addition, the correlation between the wind stress and occurrence of cold water mass (lower surface water temperature) was identified through spectral analysis.

\section{Materials and Methods}

The hourly surface water temperature data of the southeast and east coasts of Korea were measured by the weather buoys, lighthouses, and coastal wave buoys of the Korea Meteorological Administration (KMA, 2016; 2017). The hourly surface water temperature was obtained by calculating 10 averages of 6 data points measured at 10-s intervals for $10 \mathrm{~min}$ before the end of every hour; data from 2016 to 2017 were used. In addition, the data on water temperature (CTD) for August (summer) in observation lines 104 and 208 of the NIFS were also used. Table 1 summarizes the water depth, observation interval, altitude and depth of the installed measuring device, and locations of the target weather buoy, lighthouse, and coastal wave buoy (Fig. 1).

In this sea area, fluctuations in the half day and daily cycles due to tide, inertia cycles (19-21 h) caused by wind and other quasi-inertial cycles (internal wave) known as a periodic variation of approximately $1.7 \mathrm{~d}(40 \mathrm{~h})$ may exist (Thompson, 1983; Walters \& Heston, 1981). Hence, low-pass filtering was performed on each time series to remove these short-period fluctuations from the water temperature, air temperature, wind direction, and speed time series data from the 17 monitoring stations. The least-squares method was used to remove the seasonal fluctuations from the year-round time series data (Kang, 2000).

Wind data were measured at Geojedo, Ulsan, Pohang, and Donghae stations located to some extent in the open sea (measured altitude: approximately $4.0 \mathrm{~m}$ ) and at Gwangan and Iduckseo stations located along the coast (Gwangan, $12.0 \mathrm{~m}$; Iduckseo, $17.5 \mathrm{~m}$ ). The data from Gwangan station, which were complete during the period considered (especially in summer), and the altitude (approximately $10 \mathrm{~m}$ ) suitable for wind stress calculation were used for the study analysis. The wind speed 
Table 1. Locations, equipment sensor heights and depths, water depth, and measuring intervals at each station by KMA. Sensor height and depth are measured from the sea level

\begin{tabular}{|c|c|c|c|c|c|c|c|c|}
\hline \multirow[t]{2}{*}{ Station } & \multicolumn{2}{|l|}{ Location } & \multirow[t]{2}{*}{ Air tem Ht (m) } & \multirow[t]{2}{*}{ Wind $\mathrm{Ht}(\mathrm{m})$} & \multirow[t]{2}{*}{ Wat tem Dep (m) } & \multirow[t]{2}{*}{ Water Dep (m) } & \multirow[t]{2}{*}{ Obser Int (h) } & \multirow[t]{2}{*}{ Obser system } \\
\hline & Latitude & Longitude & & & & & & \\
\hline Geojedo & $34^{\circ} 46^{\prime}$ & $128^{\circ} 54^{\prime}$ & 3.4 & 4.0 & -0.3 & -87 & 0.5 & Weather buoy \\
\hline Namhang & $35^{\circ} 01^{\prime}$ & $128^{\circ} 57^{\prime}$ & - & - & -0.3 & -20 & 1.0 & Wave buoy \\
\hline Bukhang & $35^{\circ} 06^{\prime}$ & $129^{\circ} 08^{\prime}$ & - & - & -0.3 & -40 & 1.0 & Wave buoy \\
\hline Gwangan & $35^{\circ} 08^{\prime}$ & $129^{\circ} 08^{\prime}$ & 11.0 & 12.0 & -6.0 & -11 & 1.0 & Light house \\
\hline Jangan & $35^{\circ} 18^{\prime}$ & $129^{\circ} 17^{\prime}$ & - & - & -0.3 & -28 & 1.0 & Wave buoy \\
\hline Ganjeolgot & $35^{\circ} 22^{\prime}$ & $129^{\circ} 23^{\prime}$ & - & - & -0.3 & -30 & 1.0 & Wave buoy \\
\hline Ulsan & $35^{\circ} 21^{\prime}$ & $129^{\circ} 50^{\prime}$ & 3.7 & 4.0 & -0.8 & -145 & 0.5 & Weather buoy \\
\hline Iduckseo & $35^{\circ} 34^{\prime}$ & $129^{\circ} 28^{\prime}$ & 14.0 & 17.5 & -7.0 & -14 & 1.0 & Light house \\
\hline Guryongpo & $35^{\circ} 60^{\prime}$ & $129^{\circ} 35^{\prime}$ & - & - & -0.3 & -31 & 1.0 & Wave buoy \\
\hline Wolpo & $36^{\circ} 13^{\prime}$ & $129^{\circ} 24^{\prime}$ & - & - & -0.3 & -37 & 1.0 & Wave buoy \\
\hline Pohang & $36^{\circ} 21^{\prime}$ & $129^{\circ} 47^{\prime}$ & 3.7 & 4.2 & -0.8 & -310 & 0.5 & Weather buoy \\
\hline Hupo & $36^{\circ} 43^{\prime}$ & $129^{\circ} 29^{\prime}$ & - & - & -0.3 & -30 & 1.0 & Wave buoy \\
\hline Jukbyeon & $37^{\circ} 06^{\prime}$ & $129^{\circ} 23^{\prime}$ & - & - & -0.3 & -29 & 1.0 & Wave buoy \\
\hline Samcheok & $37^{\circ} 24^{\prime}$ & $129^{\circ} 14^{\prime}$ & - & - & -0.3 & -19 & 1.0 & Wave buoy \\
\hline Donghae & $37^{\circ} 33^{\prime}$ & $130^{\circ} 00^{\prime}$ & 3.7 & 4.2 & -0.8 & $-1,518$ & 0.5 & Weather buoy \\
\hline Yeongok & $37^{\circ} 52^{\prime}$ & $128^{\circ} 53^{\prime}$ & - & - & -0.3 & -29 & 1.0 & Wave buoy \\
\hline Toseong & $38^{\circ} 17^{\prime}$ & $128^{\circ} 35^{\prime}$ & - & - & -0.3 & -27 & 1.0 & Wave buoy \\
\hline
\end{tabular}

KMA, Korea Meteorological Administration.

and direction data were coordinated with the southeast coast where the Gwangan station is located. The wind stress in a direction parallel to the coast (y component) directly affecting the Ekman transport was calculated according to Equation (1);

$$
\tau_{\mathrm{y}}=\rho_{\text {air }} \cdot \mathrm{C}_{\mathrm{D}} \cdot \mathrm{W}_{\mathrm{y}}\left(\mathrm{W}_{\mathrm{x}}^{2}+\mathrm{W}_{\mathrm{y}}^{2}\right)^{1 / 2}
$$

where $\tau_{\mathrm{y}}$ is the wind stress parallel to the coast; $\rho_{\text {air }}$ is the density of the atmosphere $\left(=1.2 \times 10^{-3} \mathrm{~g} \mathrm{~cm}^{-3}\right)$; $C_{\mathrm{D}}$ is the drag coefficient; $\mathrm{W}_{\mathrm{y}}$ and $\mathrm{W}_{\mathrm{x}}$ are the wind speed components parallel (y) and perpendicular ( $\mathrm{x}$ ) to the coast, respectively. The drag coefficient, $C_{D}$, used here is obtained using Equation (2); it is expressed as a function of the wind speed $\left(\mathrm{W}=\left(\mathrm{W}_{\mathrm{x}}{ }^{2}+\mathrm{W}_{\mathrm{y}}{ }^{2}\right)^{1 / 2}\right)$ and the difference $\left(\Delta \mathrm{T}=\mathrm{T}_{\mathrm{a}}-\mathrm{T}_{\mathrm{w}}\right)$ between air temperature $\left(\mathrm{T}_{\mathrm{a}}\right)$ and seawater temperature $\left(\mathrm{T}_{\mathrm{w}}\right)$ (Hellerman \& Rosenstein, 1983).

$$
\begin{aligned}
& \mathrm{C}_{\mathrm{D}}(\mathrm{W}, \Delta \mathrm{T})=0.934+10^{-3}+0.788 \times 10^{-4} \mathrm{~W}+0.868 \times 10^{-4} \Delta \mathrm{T} \\
& -0.616 \times 10^{-6} \mathrm{~W}^{2}-0.120 \times 10^{-5} \Delta \mathrm{T}^{2}-0.214 \times 10^{-5} \mathrm{~W} \Delta \mathrm{T}
\end{aligned}
$$

The wind speed, air temperature, and seawater temperature data used in Equations (1) and (2) were obtained from the Gwangan station. The coastal cold water warning issuance information (Oceanographic data and news, NIFS [2016a; 2017]) was used. The information is based on the surface water temperature analysis of the NIFS real-time marine environment fishery information system, sea surface temperature (SST) satellite infrared images, and average SST distribution data of the southeast and east coast of Korea during the emergence of the coastal cold water mass with the least cloud blocking.

The relationship between the surface water temperature in spring and summer and atmospheric factors was identified by evaluating the temporal and spatial distributions, cross-correlation, and dominant fluctuation period by spectral density analysis. Moreover, a coherence analysis of the decrease in surface water temperature due to wind fluctuations was conducted using the wavelet coherence method of Grinsted et al. (2004). It can be assumed that fluctuations in ocean water temperature differ occasionally because of changes in external factors, such as wind, air temperature, and tides. In the case where the fluctuation characteristics change according to time (non-stationary), the implementation of a wavelet spectrum transformation is suitable. The entire time series is transformed into a partial time series by applying a specific window rather than transforming 


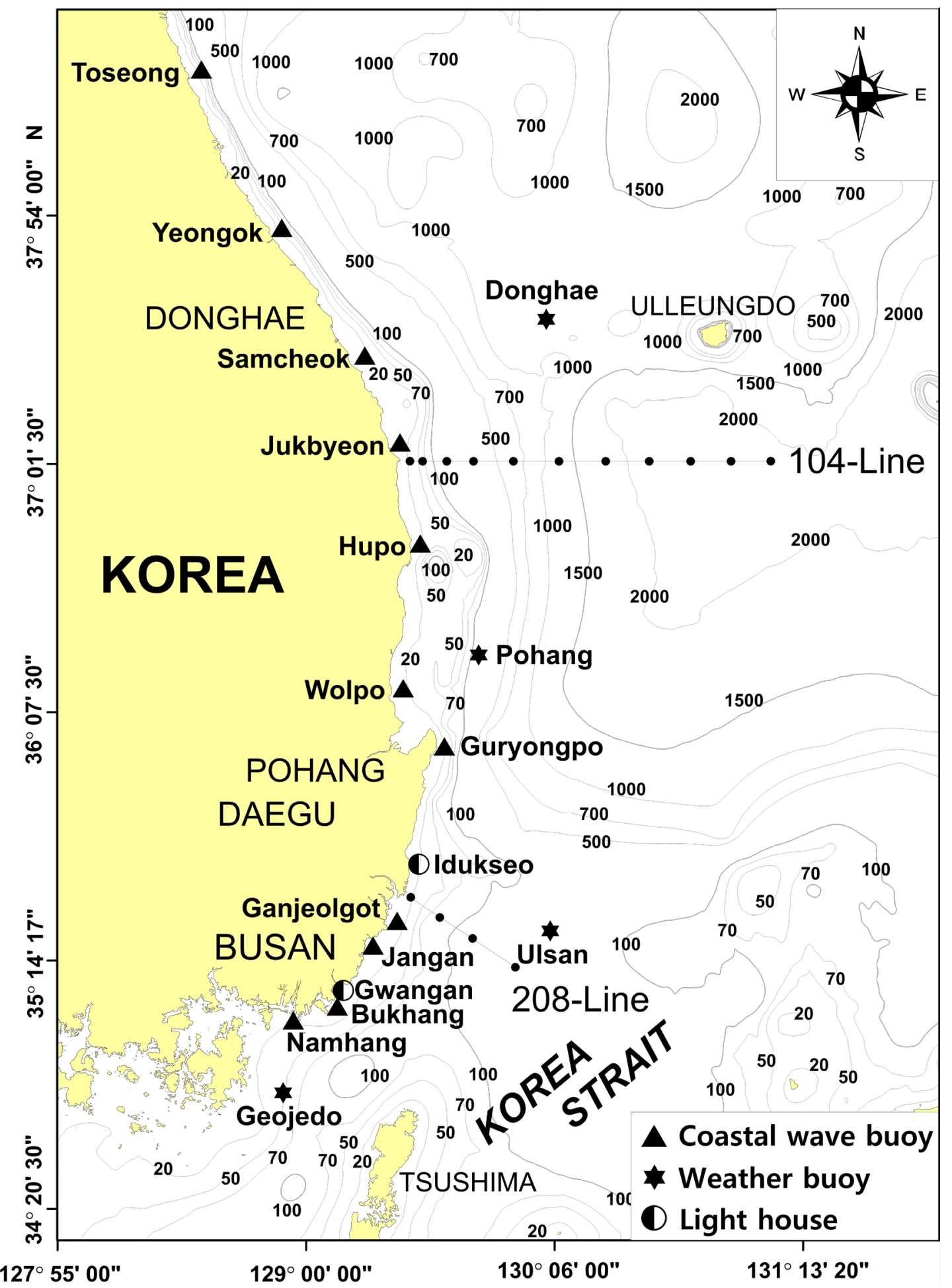

Fig. 1. Bottom topography map of study area; contours denote depth $(\mathbf{m})$. It also shows the surface water temperature monitoring stations of weather buoy, light house, and coastal wave buoy along the southeast and east coasts of Korea observed by KMA and serial oceanographic observational stations of lines 104 and 208 in the east coast of Korea observed by NIFS. Wind speed, wind direction, and air temperature are also measured by weather buoy and lighthouse automatic weather systems. KMA, Korea Meteorological Administration; NIFS, National Institute of Fisheries Science. 
the entire time series into the frequency domain at once. This method allows the analysis of the characteristics in which the dominant period of fluctuation varies with time. The formation time of the cold water mass due to coastal upwelling was measured from the time the water temperature decreased because of the wind components parallel to the coast (south-southwest wind) to the time when the water returned to its original temperature.

\section{Results}

\section{Seasonal fluctuations in water temperature and wind stress}

To understand the year-round surface water temperature fluctuations in the southeast and east coasts of Korea, the 2016-2017 water temperature time series data from 17 stations between Geojedo and Toseong were collated. To build the water temperature time series data, the $40 \mathrm{~h}$ low-pass filtered data were used to remove short-period fluctuations caused by tide and wind. The water temperature time series of nine stations from 2016 to 2017 is shown in Fig. 2. Table 2 summarizes the minimum, maximum, annual mean, and standard deviations of the surface water temperature from 17 stations; the data were averaged from 2016 to 2017. In the list, stations with long missing data during the measurement period (especially in 2017) are marked (with ${ }^{*}$ ) and excluded from the statistics for the year.

The water temperature shown in Fig. 2 varies seasonally, exhibiting the lowest in mid-February (winter) and the highest in early August (summer). The year-round minimum and maximum temperatures are $5.6^{\circ} \mathrm{C}-12.6^{\circ} \mathrm{C}$ and $27.3{ }^{\circ} \mathrm{C}-30.2^{\circ} \mathrm{C}$, respectively. They are generally high at the southeast coast and lower at the north of the east coast. Geojedo, Ulsan, Pohang, and Donghae, which are located in the open sea, have minimum and maximum temperatures of $9.0{ }^{\circ} \mathrm{C}-12.6{ }^{\circ} \mathrm{C}$ and $29.5^{\circ} \mathrm{C}-30.1{ }^{\circ} \mathrm{C}$ (higher than that of the coastal stations), respectively. The annual mean water temperature is $16.1{ }^{\circ} \mathrm{C}-19.9^{\circ} \mathrm{C}$, which decreases toward the north of the east coast and is higher in the open sea. The standard deviation is $3.98{ }^{\circ} \mathrm{C}-5.50{ }^{\circ} \mathrm{C}$, which is generally small at the southeast coast station and large at the north of the east coast station. The standard deviation of the annual mean water temperature at the offshore station is $4.57^{\circ} \mathrm{C}-5.05^{\circ} \mathrm{C}$, which is smaller than that in the coast. Therefore, by region, the southeast coast has a higher year-round water temperature and a smaller water temperature fluctuation (variation) than the east coast. The coast has a lower water temperature than the open sea and has a large annual fluctuation. One of the features of the water temperature time series in Fig. 2 is an intermittent drop in surface water temperature. It occurs several days to one week at the southeast coast (BukhangIduckseo) and every several days on the east coast (HupoYeongok) from April to September. The duration and coverage of the water temperature decrease are longer and wider at the southeast coast than at the north of the east coast; the drop in
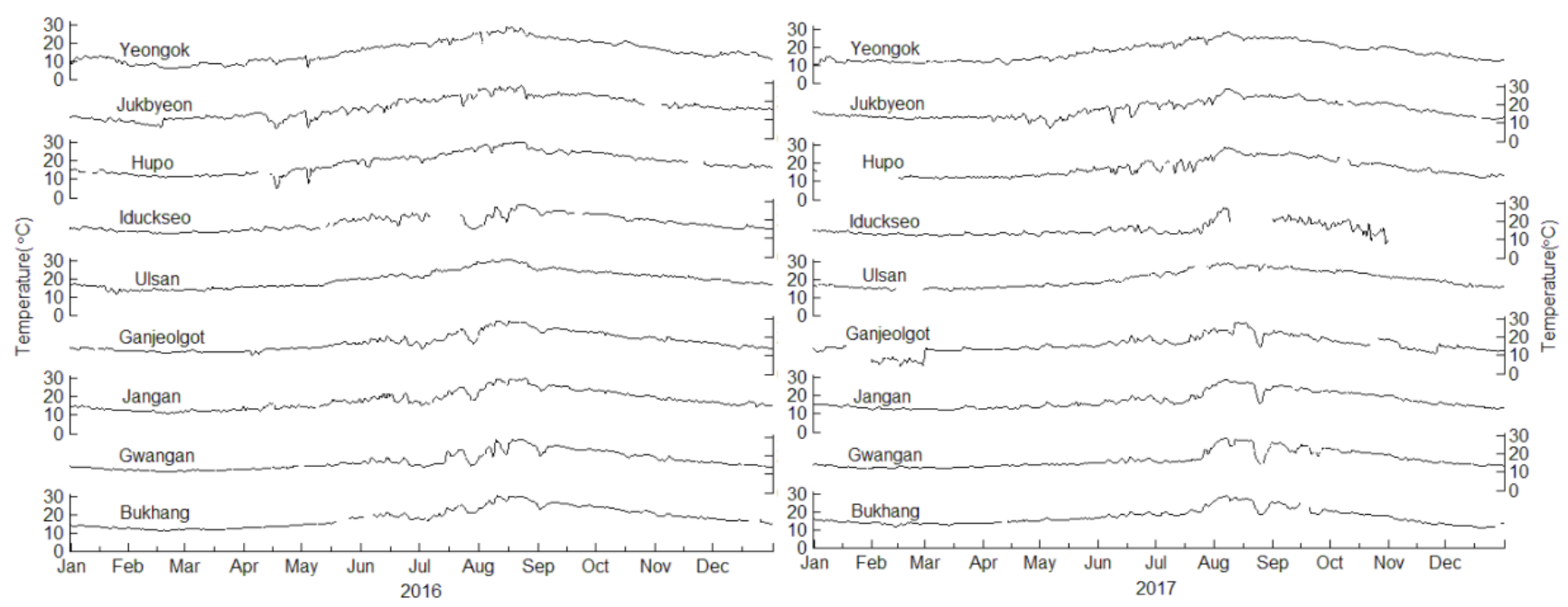

Fig. 2. Time series of low-pass filtered surface water temperature at Bukhang, Gwangan, Jangsan, Ganjeolgot, Ulsan, Iduckseo, Hupo, Jukbyeon, and Yeongok stations along southeast and east coasts of Korea as observed by Korea Meteorological Administration (KMA) from January 2016 to December 2017. 
Table 2. Statistics of low-pass filtered surface temperatures from monitoring stations between Geojedo and Toseong (January 2016-December 2017)

\begin{tabular}{lllll}
\hline Station & Min. $\left({ }^{\circ} \mathrm{C}\right)$ & Max. $\left({ }^{\circ} \mathrm{C}\right)$ & Mean $\left({ }^{\circ} \mathrm{C}\right)$ & S.D. $\left({ }^{\circ} \mathrm{C}\right)$ \\
\hline Toseong* & 5.6 & 27.3 & 14.9 & 5.50 \\
Yeongok & 8.0 & 28.6 & 16.3 & 5.39 \\
Donghae & 9.0 & 29.5 & 18.2 & 5.05 \\
Samcheok & 6.2 & 28.3 & 16.1 & 4.93 \\
Jukbyeon & 6.1 & 28.7 & 16.9 & 5.10 \\
Hupo & 8.3 & 29.5 & 18.1 & 5.07 \\
Pohang & 10.8 & 29.6 & 18.5 & 4.71 \\
Wolpo & 8.4 & 28.3 & 17.4 & 4.81 \\
Guryongpo* & 8.1 & 29.1 & 18.5 & 4.23 \\
Iduckseo* & 12.4 & 28.3 & 18.1 & 3.98 \\
Ulsan & 12.6 & 29.9 & 19.9 & 4.57 \\
Ganjeolgot & 10.0 & 28.9 & 17.4 & 4.60 \\
Jangan & 11.4 & 29.4 & 17.5 & 4.63 \\
Gwangan & 11.6 & 28.7 & 16.8 & 4.39 \\
Bukhang & 11.0 & 29.6 & 17.6 & 4.72 \\
Namhang & 10.1 & 30.2 & 18.5 & 5.47 \\
Geojedo & 12.5 & 30.1 & 19.2 & 4.68 \\
\hline
\end{tabular}

*with missing data in 2017.

the water temperature at Gwangan is particularly remarkable. In offshore stations such as Ulsan, this drop is not noticeable.

The water temperature time series at the five coastal stations and the wind vector and air temperature time series at Gwangan, which is the measurement station for atmospheric elements, are shown in Fig. 3. The water temperature, air temperature, and wind speed time series are shown after $40 \mathrm{~h}$ of low-pass filtering and removal of seasonal fluctuations. From 2016 to 2017, the wind blows from northwest to northeast (vector direction is southeast to southwest) in winter (January-March) and autumn (September-December). However, in spring (April-June) and summer (July-August), the winds blowing from southwest to south-southwest (northeast to north-northeast in the vector direction) are dominant. In comparing the periods with significant (April-September) and insignificant temperature reductions in the water temperature time series, the south-southwest wind generally blows excellently during the former period. The water temperature fluctuation is not considerably large during the period that the northwest and northeast winds blow. However, the air temperature time series had greater temperature fluctuations when the northwest-northeast winds blew rather than the southwestern winds.
The south-southwest wind excellently blows in spring and summer; however, after three consecutive days, the wind direction rapidly changes to that of the north-northeast wind (e.g., July-August 2017), and the water temperature fluctuates. The magnitude and duration of the water temperature fluctuations vary depending on the period and intensity of the southwestern and northeastern winds; the interaction between the wind and water temperature frequently occurs during this period. The stations where the water temperature fluctuation range is considerable are generally on the east (Hupo and Jukbyeon) and southeast coasts (Gwangan, Jangan, and Ganjeolgot) from April to June and from July to September. The drops in water temperature observed in Jukbyeon and Hupo in April-May 2016 and May-June 2017 are not remarkable in the southeast coast below Ganjeolgot. The fluctuation amplitude of the significant drop and rise in water temperature in July-August at Gwangan, Jangan, and Ganjeolgot is reduced or reversed from Hupo to Jukbyeon.

\section{Comparison of satellite infrared data with cold water mass development}

The water temperature drop (cold water) phenomenon due to the southwest monsoons occurred in the spring and summer of 2016-2017. The wind data of the Gwangan station during this period were transformed to be parallel to the southeast coast of Korea; the wind direction was rotated $30^{\circ}$ clockwise from the north. The wind stress time series of components parallel to the coast and the water temperature time series are shown in Fig. 4. The wind stress has a negative value because of the wind component of the southwestern wind parallel to the southeast coast. The negative (-) wind stress represents the wind component of the south-southwest wind (wind direction: $210^{\circ}$ ) blowing along the southeast coast. The squares indicated by arrows and dotted lines in the figure represent the time when the water temperature decreases at the stations of the southeast coast below Guryongpo, and the water temperature rises at the stations on the east coast at the end of July 2016. The distribution of surface water temperature around the southeast and east coasts of Korea that are obtained by satellite infrared images during this period (July 29-30 2016) is shown in Fig. 5.

In April-May 2016, when the wind stress is negative, reductions in water temperature are observed on the east coast for several days; however, the water temperature fluctuations are not considerably noticeable on the southeast coast. In contrast, from June to July 2016, the water temperature drop is large on 

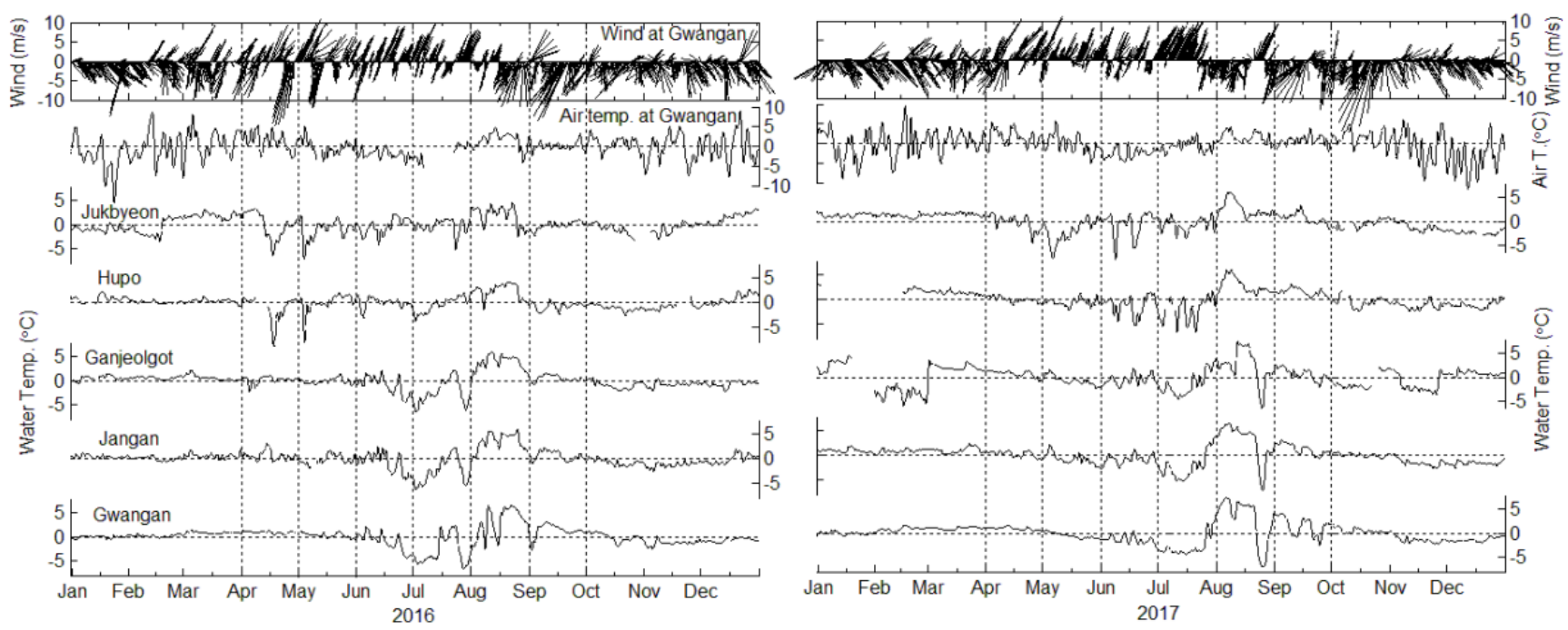

Fig. 3. Time series of low-pass filtered surface water temperatures at Gwangan, Jangan, Gangeolgot, Hupo, and Jukbyeon stations; air temperature and wind vector at Gwangan station from January 2016 to December 2017. Seasonal changes are removed from surface water and air temperatures.
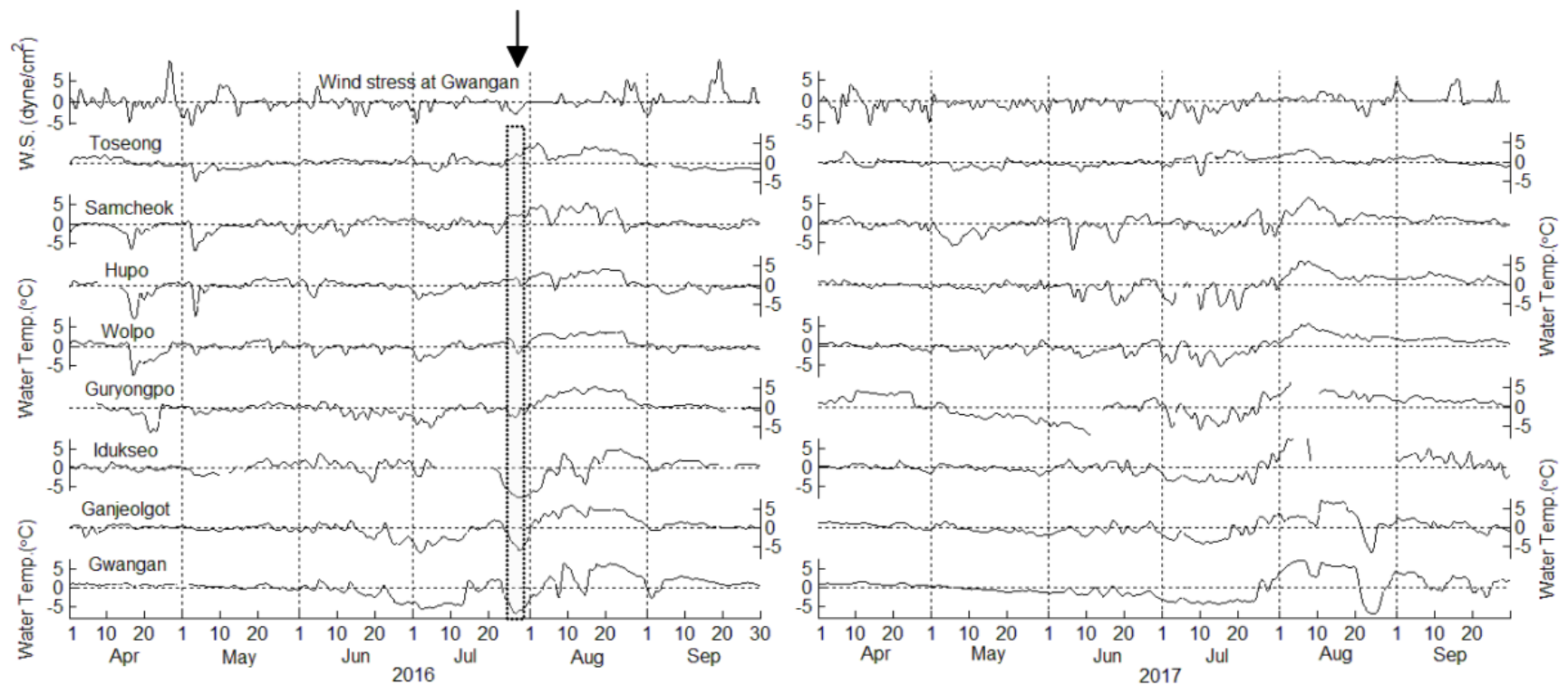

Fig. 4. Time series of low-pass filtered surface water temperatures at Gwangan, Ganjeolgot, Iduckseo, Guryonpo, Hupo, Samcheck, and Toseong stations; wind stress measured at Gwangan station from April 1 to September 30 of 2016 and 2017. The arrow and rectangular area that are marked by dotted lines in the figure indicate the period of the cold water formation on the southeast coast near the end of July 2016 and when the wind stress components parallel to the shore are negative.

the southeast coast; on the east coast, there is either no change in water temperature or the increase is inconsiderable. In $\mathrm{Au}$ gust 2016, a rise in water temperature occurs in all sea areas because of the positive wind stress. In September, a slight water temperature drop and rise are observed on the east and southeast coasts, respectively. Different from the wind stress and water temperature fluctuations in 2016, in May-September 2017 the water temperature in most stations decreases and increases 

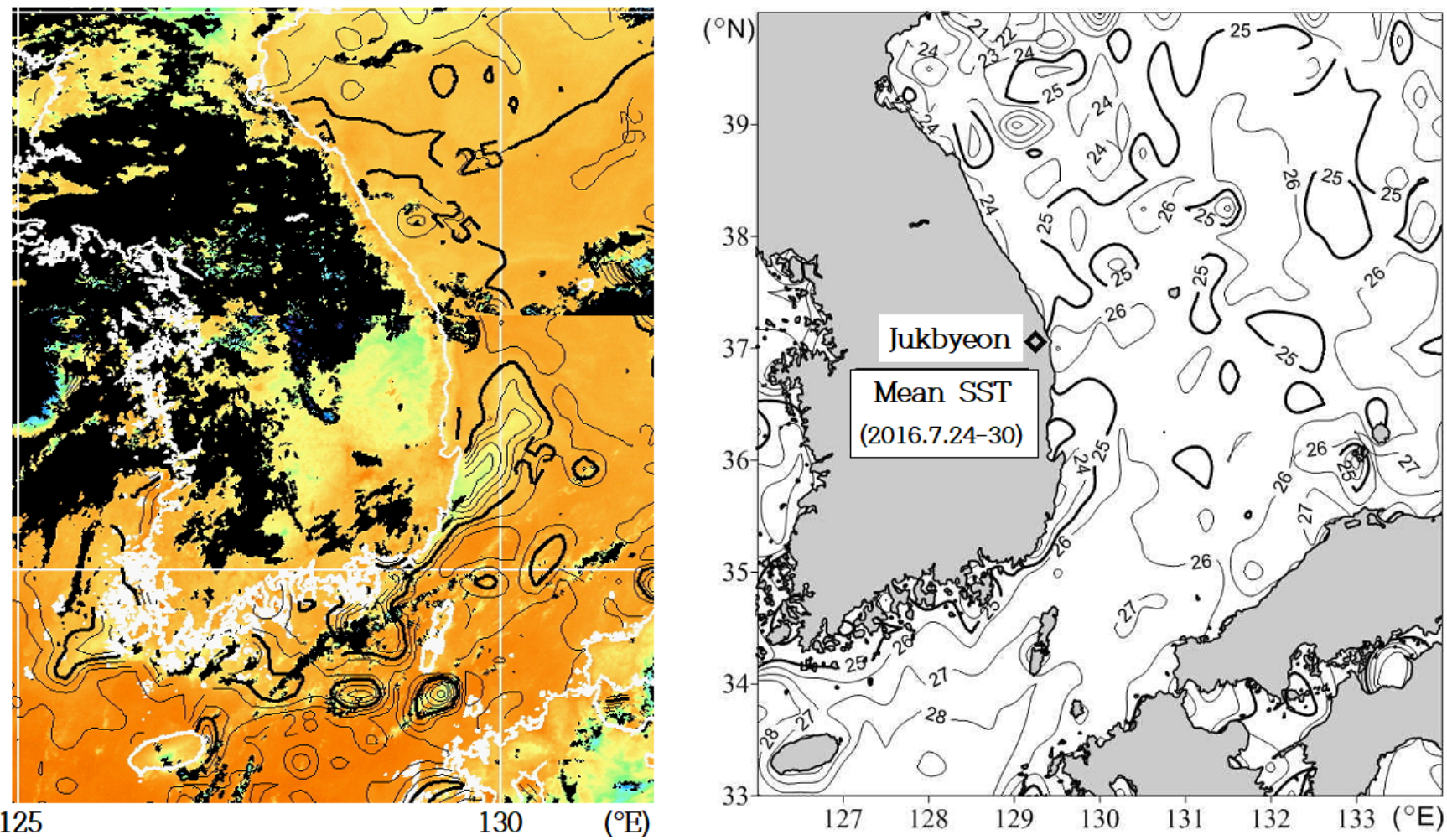

Fig. 5. To eliminate the blocking effect of clouds in the satellite infrared imagery (left), the north of Jukbyeon image ( $37^{\circ} \mathrm{N}$ ) at 03:24 (July 30) includes the south of Jukbyeon image at 03:36 (July 29, 2016). Adapted from NIFS (2016b; 2016c) with CC-BY. The figure on the right shows the mean composite sea surface temperature (weekly oceanic conditions in the East and South seas of Korea) generated from week-long satellite infrared imageries from July 24-30, 2016. NIFS, National Institute of Fisheries Science.

due to negative and positive wind stresses, respectively. Accordingly, in some stations, the wind stress and water temperature fluctuations are well reflected. In 2016, some stations occasionally experienced the foregoing. It is observed that the change in water temperature in the coastal area due to wind stress differs depending on the time and location (i.e., position relative to the direction in which the wind stress acts).

The distribution of surface water temperature around Korea in July 29-30, 2016 obtained using infrared images and the distribution of cold water mass centered on the southeast coast are shown in Fig. 5 (left). The center of the cold water mass is estimated to be in the proximity of Gwangan and Iduckseo, and the water temperature is approximately $20^{\circ} \mathrm{C}$. In the coast of Ganjeolgot and Guryongpo, the temperature of the cold water area is $21^{\circ} \mathrm{C}-24^{\circ} \mathrm{C}$; it is distributed way into the open sea from the northeast to north-northeast direction. However, in Wolpo-Toseong on the east coast, the temperature is approximately $25^{\circ} \mathrm{C}$, and different from the southeast coast, the cold water phenomenon due to coastal upwelling is not observed. The distribution of surface water temperature in the seas around the south and east coasts of Korea based on satellite observation data for $7 \mathrm{~d}$ (July 24-30, 2016) is shown in Fig. 5 (right). The water temperature is approximately $25^{\circ} \mathrm{C}$ on the east coast in Jukbyeon; the water temperature distributed on the southeast coast from Bukhang (Gwangan) to Guryongpo is less than $24^{\circ} \mathrm{C}$. Therefore, in comparing the one-week average water temperature distribution (Fig. 5 (right)) and the $1 \mathrm{~d}$ water temperature data (July 29-30; Fig. 5 (left)), it is observed that the appearance of cold water mass with a temperature of less than $24^{\circ} \mathrm{C}$ due to coastal upwelling during this period is generally developed along the southeast coast of Guryongpo and below it. Moreover, the water temperature drop is not remarkable on the east coast of Wolpo with a water temperature distribution of approximately $25^{\circ} \mathrm{C}$. The extent of this water temperature drop (coastal upwelling) according to the sea area is also evident in the time series distribution of wind stress and surface water 
temperature at each station (Fig. 4).

\section{Vertical structure of water temperature during cold water mass formation (August)}

The vertical water temperature cross-sectional views from the August water temperature (CTD) data of coastal observation lines 208 and 104 in 2016 and 2017 are shown in Fig. 6. Observation line 208 is located between Ganjeolgot and Iduckseo, and observation line 104 is near the coast of Jukbyeon. The investigation of observation line 208 only lasts for $1 \mathrm{~d}$ because the observation stations are few (i.e., 4), and that of observation line 104, which has 11 stations, lasts 2-3 d. In August 2016 (Fig. 6, upper left), the surface water temperatures from Sta.01 to Sta.02 and from Sta. 02 to Sta.04 of observation line 208 are $22^{\circ} \mathrm{C}-28^{\circ} \mathrm{C}$ and approximately $30^{\circ} \mathrm{C}$, respectively. The horizontal gradient of the surface water temperature from Sta.01 to Sta.02 close to the coast is considerably large. In addition, as the cold water mass develops along the coast, the vertical gradient of the isotherms becomes large; the isotherms exhibit a distribution that is inclined toward the open sea (Suh et al., 2001). In August 2017, in observation line 208 (Fig. 6, lower left), the surface water temperatures from Sta.01 to Sta.02 and from Sta.02 to Sta.04 are $22^{\circ} \mathrm{C}-26^{\circ} \mathrm{C}$ and above $26^{\circ} \mathrm{C}$, respectively; the water temperature is lower than that in 2016, but the slope of the isotherm is similar. In the water temperature time series at Ganjeolgot and Iduckseo (Fig. 4), the cold water phenomenon, which is confirmed to be caused by the southwest wind, emerges during the two periods above.

In contrast, in the vertical water temperature profile of observation line 104 in front of Jukbyeon in 2016 (Fig. 6, upper right), warm water is distributed at a depth of approximately $150 \mathrm{~m}$ of Sta.09 and at a depth of 20-300 $\mathrm{m}$ in the vertical direc-
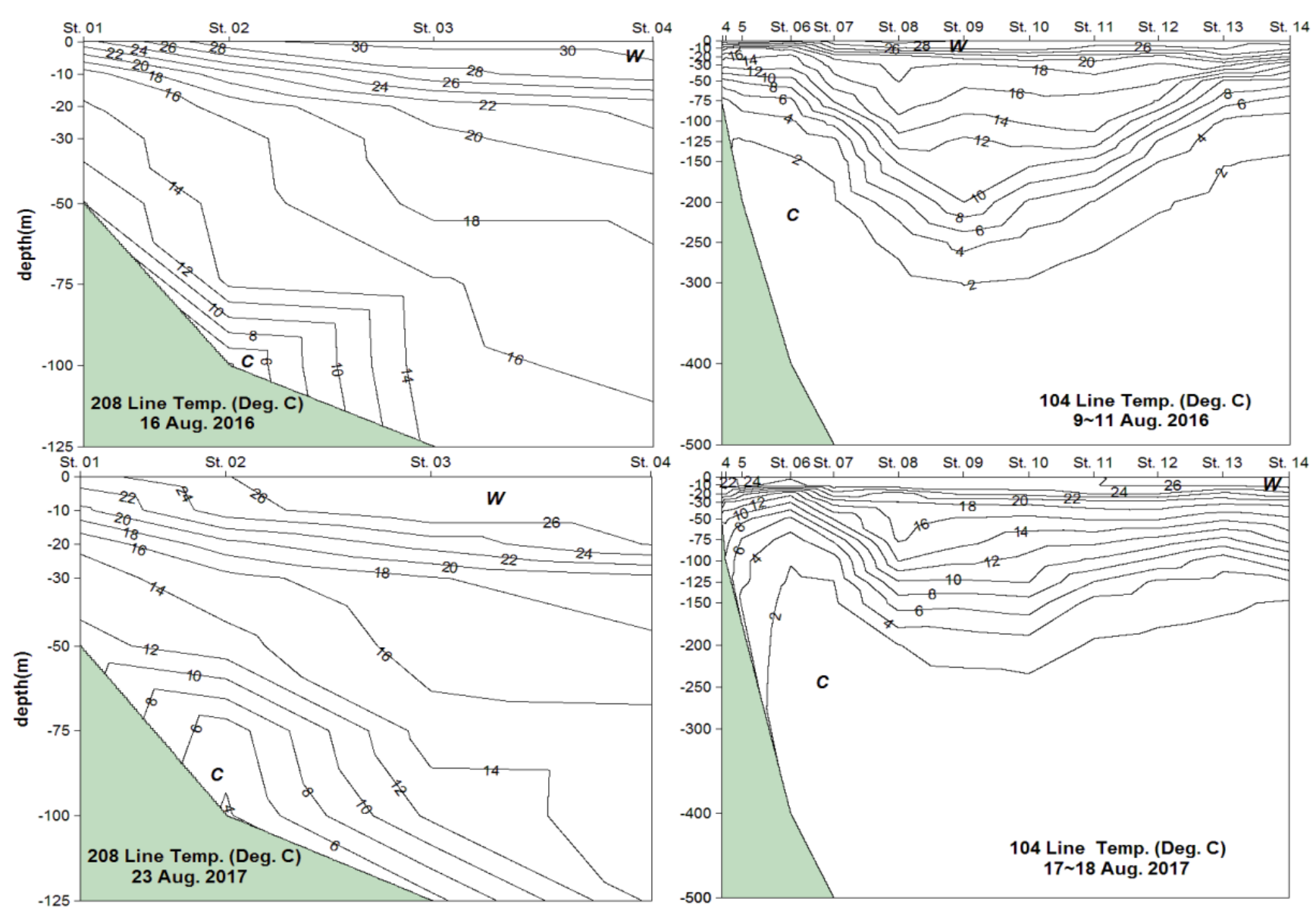

Fig. 6. Vertical distributions of water temperature along NIFS cruise: line 208 (left panel) and line 104 (right panel) in August of 2016 and 2017. NIFS, National Institute of Fisheries Science. 
tion from Sta.06 to Sta.13 in the horizontal direction. The water temperature is $20^{\circ} \mathrm{C}-28^{\circ} \mathrm{C}$ up to $20 \mathrm{~m}$ in the surface water layer; temperature stratification is developed, and the water temperature near the coast does not drop. In 2017 (Fig. 6, lower right), cold water is distributed at a depth of 20-200 m from Sta.05 to Sta.07; warm water is distributed from Sta.08 to Sta.11, and the 0-20-m surface layer has a water temperature stratification of $20^{\circ} \mathrm{C}-26^{\circ} \mathrm{C}$. Therefore, the upwelling of the lower water layer is insignificant, such as that in observation line 208 at the station adjacent to the coast. In addition, on August 9-11, 2016 and August 17-18, 2017, no water temperature drops at the Jukbyeon and Samcheok stations due to wind stress are observed (Figs. 3 and 4).

\section{Temporal and spatial fluctuations of surface water tempera- ture in spring and summer}

To understand the temporal and spatial fluctuations of coastal water temperature when the southwest seasonal wind is dominant, the fluctuations of surface water temperature at mooring stations from April 1 to September 30 of 2016 and 2017 are shown in Fig. 7. The vertical axis in the figure shows 13 coastal stations from Namhang to Toseong; the stations in Geojedo, Ulsan, Pohang, and Donghae located in the open sea are not shown in the figure. The blanks in the image are areas where data are not available because of data collection problems. From early April to mid-May of 2016 and 2017, the extreme temperature of the cold water mass from Wolpo to Toseong dominate the surroundings. The water temperature at the center of the cold water mass from Jukbyeon to Samcheok is $8{ }^{\circ} \mathrm{C}-12^{\circ} \mathrm{C}$, which is $4{ }^{\circ} \mathrm{C}-8^{\circ} \mathrm{C}$ lower than the surrounding sea area $\left(16^{\circ} \mathrm{C}\right)$. From mid-June to mid-August 2016, cold water masses emerge from Bukhang (the station between Namhang and Gwangan shown in Fig. 7) to Wolpo, and from Jukbyeon to Toseong. The cold water areas are from Gwangan to Iduckseo and from Samcheok to Yeongok; the central temperature of the cold water is $14^{\circ} \mathrm{C}-16^{\circ} \mathrm{C}$, which is $8^{\circ} \mathrm{C}-12^{\circ} \mathrm{C}$ lower than that in the in the nearby sea area (i.e., $22^{\circ} \mathrm{C}-28^{\circ} \mathrm{C}$ ). From the end of July to mid-August, the cold water mass (water temperature: approximately $14^{\circ} \mathrm{C}$ ) gradually develops from Bukhang to Guryongpo of the southeast coast, and the water temperature is $10^{\circ} \mathrm{C}-14^{\circ} \mathrm{C}$ lower than that of the surrounding area (i.e., $24^{\circ} \mathrm{C}-28{ }^{\circ} \mathrm{C}$ ); hence, it is during this period of the year that the cold water mass is dominant. After September, the temperature from Samcheok to Toseong is $20^{\circ} \mathrm{C}-22^{\circ} \mathrm{C}$, which is $2{ }^{\circ} \mathrm{C}-4{ }^{\circ} \mathrm{C}$ lower than the temperature of the surrounding area $\left(24{ }^{\circ} \mathrm{C}-26^{\circ} \mathrm{C}\right)$. From mid-June to late July 2017, the water temperature from Iduckseo to Samcheok and from Gwangan to Jukbyeon is $12^{\circ} \mathrm{C}-14^{\circ} \mathrm{C}$, which is $6{ }^{\circ} \mathrm{C}-8{ }^{\circ} \mathrm{C}$ lower than the temperature of the surround-
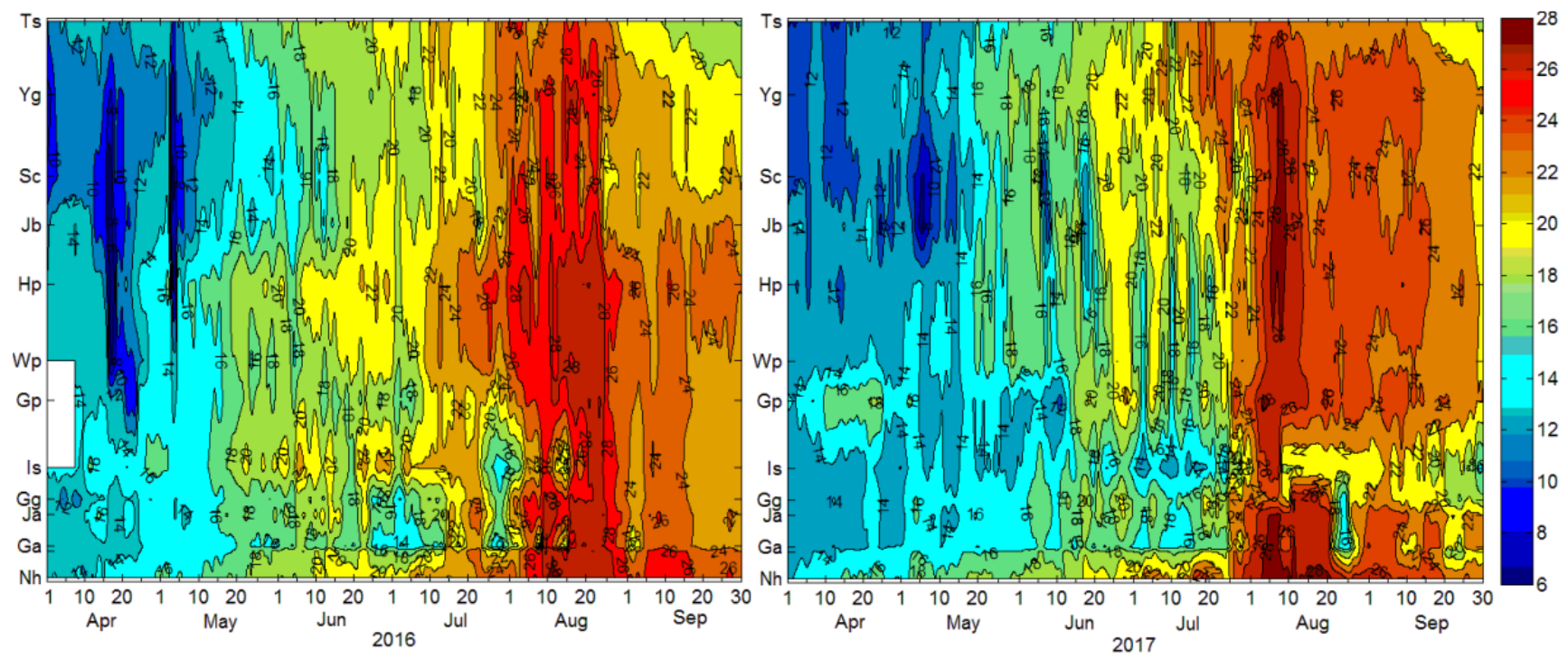

Fig. 7. Variations of the low-pass filtered surface water temperature data at monitoring stations of buoy, lighthouse, and coastal wave buoy along the southeast and east coasts of Korea from April 1 to September 30 of 2016 and 2017. In the figure, the abbreviations Nh, Ga, Ja, Gg, Is, Gp, Wp, Hp, Jb, Sc, Yg, and Ts refer to Namhang, Gwangan, Jangan, Ganjeolgot, Iduckseo, Guryongpo, Wolpo, Hupo, Jukbyeon, Samcheok, Yeongok, and Toseong monitoring stations, respectively. 
ing area $\left(20^{\circ} \mathrm{C}\right)$. The cold water mass is distributed from Gwangan to Samcheok, centering on Iduckseo. From mid-August to late September, the temperature from Namhang to Guryongpo is $16^{\circ} \mathrm{C}-20^{\circ} \mathrm{C}$, which is $8{ }^{\circ} \mathrm{C}-10^{\circ} \mathrm{C}$ lower than the surrounding temperature $\left(24^{\circ} \mathrm{C}-26^{\circ} \mathrm{C}\right)$; the extreme temperature of the cold water mass is dominant throughout the year. The center of the cold water mass is estimated to be at Gwangan-Iduckseo. Cold water generally appears in Toseong and Yeongok in April; Samcheok and Jukbyeon in May; Wolpo and Guryongpo in June; Iduckseo in July; from Iduckseo to Gwangan in August and September. The center of the cold water mass gradually moves from the north to the southeast coast from spring to summer. In other words, before mid-May (from early April to early May), cold water masses are formed around the north (Toseong-Samcheok) and spread to the southeast (Gwangan and Bukhang); thereafter (from late May to mid-July), the cold water spreads from the southeast coast (Guryongpo-Iduckseo) to the east coast (Hupo-Jukbyeon-Samcheok). However, from mid-August to late September, cold water masses are only distributed from Bukhang to Iduckseo on the southeast coast; they do not spread to the north.

\section{Dominant fluctuation period of water temperature, air tem- perature, and wind}

To understand the short-term fluctuations in water temperature at the 17 coastal mooring stations and wind and air temperatures at the 6 stations (Geojedo, Pohang, Ulsan, Gwangan, Iduckseo, and Donghae), the dominant fluctuation periods were analyzed from the time series data (April-September of 2016 and 2017), which were $30 \mathrm{~d}$ high-pass filtered. The results are summarized in Tables 3 and 4 . The frequency of the dominant period listed in the tables indicates the number of times each period appears at the corresponding station after converting the frequency (with the maximum energy density from the first to the third positions in the spectrum analysis) into a period. The dominant periods (Table 3) are $1 \mathrm{~d} ; 7.3-8.7 \mathrm{~d}$ (approximately $7 \mathrm{~d}$ ); 9.2-10.8 d (approximately $10 \mathrm{~d}$ ); 11.4-13.1 d (approximately $12 \mathrm{~d}$ ); 14.1-16.6 d (approximately $15 \mathrm{~d}$ ); 18.3 d; $20.3-26.1 \mathrm{~d}$ (approximately $23 \mathrm{~d}$ ). In general, the daily fluctuations due to the difference in specific heat between land and seawater, and the fluctuations before and after 7 to $21 \mathrm{~d}$ due to air temperature and wind are dominant. The most frequent occurrence period is approximately $15 \mathrm{~d}$, and it dominates the rest of the stations except Guryongpo, Wolpo, and Yeongok. In

Table 3. Frequency of predominant fluctuation periods (unit: $\mathrm{d}$ ) of $\mathbf{3 0} \mathbf{d}$ high-pass filtered surface water temperatures measured from Geojedo to Toseong stations in 2016 and 2017

\begin{tabular}{|c|c|c|c|c|c|c|c|c|}
\hline Sta. & 1.0 & $5.1-6.3$ & $7.3-8.7$ & $9.2-10.8$ & $11.4-13.1$ & $14.1-16.6$ & 18.3 & $20.3-26.1$ \\
\hline Toseong & 2 & & & & 1 & 1 & & 2 \\
\hline Yeongok & 2 & & 1 & & 1 & & & 2 \\
\hline Donghae & 1 & & & & & 2 & 1 & 2 \\
\hline Samcheok & & & & & & 1 & 2 & 3 \\
\hline Jukbyeon & & & & 1 & 1 & 2 & & 2 \\
\hline Hupo & & & & & 1 & 3 & & 1 \\
\hline Pohang & & & & 1 & & 2 & & 3 \\
\hline Wolpo & 1 & & 1 & & 1 & & 1 & 2 \\
\hline Guryongpo & & & & 2 & 1 & & 1 & 2 \\
\hline Iduckseo & & & & & & 1 & 2 & 3 \\
\hline Ulsan & & & & 2 & & 1 & & 3 \\
\hline Ganjeolgot & & & & & & 3 & 1 & 2 \\
\hline Jangan & & & & 1 & 1 & 2 & 1 & 1 \\
\hline Gwangan & & & & & & 4 & 1 & 1 \\
\hline Bukhang & & & & & & 4 & 1 & 1 \\
\hline Namhang & & & & & & 4 & 1 & 1 \\
\hline Geojedo & 1 & & & & & 3 & 1 & 1 \\
\hline Total & 7 & & 2 & 7 & 7 & 33 & 13 & 32 \\
\hline
\end{tabular}


particular, the frequent fluctuation in the southeast coast from Geojedo to Ganjeolgot is approximately $15 \mathrm{~d}$ and that at the east coast from Ganjeolgot to Toseong is approximately $23 \mathrm{~d}$. The fluctuation period of approximately $23 \mathrm{~d}$ is observed among all stations. All periods of water temperature fluctuations also appeared in the periods of dominant fluctuations in wind speed and air temperature (Table 4). The x-component of wind speed is perpendicular to the southeast coast (the $\mathrm{y}$-component is parallel to the southeast coast). The dominant $1 \mathrm{~d}$ fluctuation period only appears in the $\mathrm{x}$ component of wind speed and air temperature. The dominant period of wind speed is $11.4-13.1 \mathrm{~d}$ (approximately $12 \mathrm{~d}$ ) and that of air temperature is $14.1-16.6 \mathrm{~d}$ (approximately $15 \mathrm{~d}$ ).

\section{Correlation with period of water temperature drop caused by wind}

The relationship between the wind stress parallel to the southeast coast and the change in surface water temperature with different dominant periods depending on the time was analyzed in the frequency domain using the wavelet spectral transformation. Then, the wavelet coherence (correlation) for the corresponding period fluctuation was calculated. Fig. 8 shows the results at Gwangan station. In the figure, the color turning to red indicates that the correlation increases, and the arrow indicates the phase of the two time series changes. If the arrow is directed to the right $(\rightarrow)$, the phase is coincident (wind speed (stress) increase-water temperature increase); if the arrow is directed to the left $(\leftarrow)$, the phase is opposite (wind speed increase-water temperature decrease). Therefore, for winds parallel to the

Table 4. Frequency of predominant fluctuation periods (unit: $\mathbf{d}$ ) of $\mathbf{3 0} \mathbf{d}$ high-pass filtered offshore (Wind $\mathrm{x}$-co.) and alongshore (Wind y-co.) wind velocities and air temperatures(Air tem.) measured at Gejedo, Pohang, Ulsan, Gwangan, Iduckseo, and Donghae stations in 2016 and 2017

\begin{tabular}{lcccccccc}
\hline Met. Items & 1.0 & $5.1-6.3$ & $7.3-8.7$ & $9.2-10.8$ & $11.4-13.1$ & $14.1-16.6$ & 18.3 & $20.3-26.1$ \\
\hline Wind $x$-co. & 8 & 6 & 7 & & 8 & 3 & 2 & 2 \\
Wind y-co. & & 5 & 6 & 5 & 5 & 13 & 10 & 3 \\
Air tem. & 8 & & 4 & 5 & 1 & 5 \\
\hline
\end{tabular}

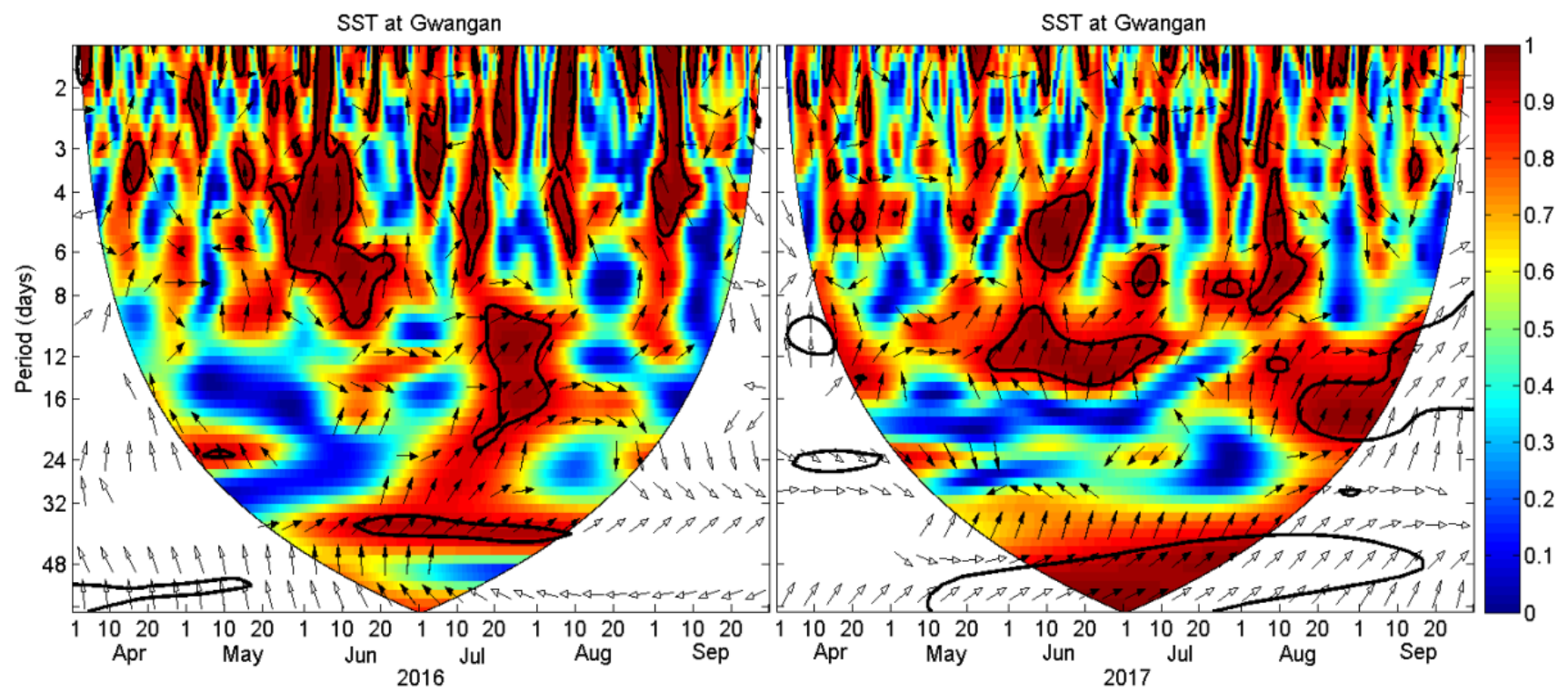

Fig. 8. Squared wavelet coherence between the alongshore wind stress and surface water temperatures at Gwangan station from April 1 to September $\mathbf{3 0}$ of $\mathbf{2 0 1 6}$ and 2017. The 95\% confidence level is shown as a thick contour; colored areas depict cone of influence. 
southeast coast (southwestern wind component), there exists a phase difference in which the water temperature drop is delayed by a clockwise angle from the left $(\leftarrow)$ arrow position. The analysis includes an increase in water temperature due to the opposite wind direction (north-north eastern wind); however, the focus is on the decrease in water temperature due to coastal upwelling. An area outside the colored region (cone) is one that cannot be analyzed; an area enclosed by a thick solid line has a reliability of $95 \%$ or more. Because both time series used in the analysis are filtered to reduce the periodic components of $40 \mathrm{~h}$ or less by $50 \%$ or more, the results for periods of less than $2 \mathrm{~d}$ are physically meaningless.

In the $95 \%$ confidence area of periods longer than $2 \mathrm{~d}$, the arrows at Gwangan (Fig. 8) and other stations are generally directed upward (from northwest to northeast). Therefore, the wind speed increase-water temperature decrease is interpreted as having a phase difference of approximately $12 \mathrm{~h}$ in a $2 \mathrm{~d}$ period; $18 \mathrm{~h}$ in a $3 \mathrm{~d}$ period; approximately $1.5 \mathrm{~d}$ in $4-8 \mathrm{~d}$ period; $2-3$ $\mathrm{d}$ in $8-24 \mathrm{~d}$ period. The northwest-northeast direction arrows within the 95\% confidence area of June-August 2016 (summer) have a high correlation in the period of 3-8 d in June and 3-8d, 8-24 d in July. However, in 2017, there is a strong correlation in the period of 4-6, 8-12 d in June, and 3-8, 12-24 d in August. The change in the periodicity between cold water emergence and dominant wind is thought to be a change according to the year of the monsoon wind. However, there is no significant difference in the direction of the arrows in Fig. 8 throughout the summer period of 2016 and 2017, indicating that there is little difference in the response time of the water temperature drop due to the blowing of the south-southwest wind even if blowing cycle is different.

The correlation differs at each station depending on the fluctuation period and time; however, the overall trend exhibits a strong correlation between 1) Geojedo-Namhang (south coast), 2) Bukhang-Iduckseo (southeast coast), 3) GuryongpoJukbyeon (central east coast), and 4) Samcheok-Toseong (north east coast). From Geojedo to Namhang, weak correlations appear in most periods, such as 3-7 d and 8-21 d from April to June; however, the correlation is extremely low in July and September. The stations from Bukhang to Iduckseo are highly correlated in most periods from May to August. From Guryongpo to Jukbyeon, the correlation is high in the 3-7 d period from June to July, but the correlation is low for periods longer than 8 d. Most stations from Samcheok to Toseong are less correlated than other stations in most of the period. All stations are highly correlated in the 2-3 d period from April to June; stations from Bukhang to Guryongpo from July to August; from Yeongok to Toseong from August to September. Periods longer than 8 $\mathrm{d}$ are relatively correlated from May to August at the Bukhang and Gwangan stations, and June to August at the Jangan to Guryongpo stations; however, the correlation from Wolpo to Toseong stations is low except from July to August.

\section{Discussion}

\section{Emergence of cold water mass in spring and summer}

In the spring and summer of 2016 and 2017, the water temperature on the southeast coast and east coast dropped for several days. The temperature drop was longer and more considerable in the southeast coast than in the east coast (Fig. 2), and the offshore stations did not have this drop in water temperature. The drop in water temperature in spring and summer is a phenomenon caused by the emergence of cold water due to the monsoon wind during the period. Moreover, the drop in water temperature differs at each seawater temperature monitoring station. This is presumed to be because the decrease in water temperature depends on the wind direction blowing in the sea area, location of the station, water depth, and coastal terrain. In the comparing the water temperature, wind, and air temperature time series (Fig. 3), the remarkable drop in water temperature at the time when the south-southwest wind excellently blows means that the surface water temperature at these stations reacts sensitively to changes in wind, especially wind direction, rather than changes in air temperature. The wind stress parallel to the southeast coast (south-southwest wind) and the surface water temperature are inversely correlated; hence, as the stress increases, the surface water temperature decreases (Fig. 3). The inverse correlation was high in the southeast coastal stations and gradually decreased toward the north coastal stations. The correlation between wind and coastal surface water temperature fluctuations varies according to the time and sea area. Overall, when the wind parallel to the coast (southwest wind) blows continuously over a long time, the surface water temperature gradually decreases and cold water mass is formed. Thereafter, when the wind blows in the opposite direction (northeast wind), the water temperature recovers or rises rapidly. The drop in water temperature is considered to be a coastal upwelling of cold water in the lower layer because of interactions between the wind and coastal shape, seabed topography, water depth, and surrounding sea conditions. 


\section{Surface water temperature fluctuations due to wind stress}

As a common phenomenon in the summer season (JuneSeptember) of 2016 and 2017, the phases of fluctuation in wind stress and water temperature were more consistent from the north coast to the southeast coast (Fig. 4). This is presumed to be because the wind stress data used in the analysis are from the southeast coast (Gwangan station) where the interaction between the water temperature and wind in the sea area is well established. However, in comparing the wind time series of Geojedo, Ulsan, Iduckseo, Pohang, and Gwangan stations located on the southeast coast of the same period and Donghae station located on the east coast, there was no significant difference in the wind direction and wind speed between the south-southwest and north-northeast monsoon winds at these stations. Therefore, in 2016 and 2017, the water temperature drop (cold water mass) in the southeast sea coast in spring and summer can be explained by the coastal upwelling reaction of the cold water in the lower layer due to the wind blowing parallel to the coast while directed to the coast where the measurement stations are located. The existing study using satellite infrared images (Lee et al., 1998) on the development of cold water mass in the southeast coastal areas of Korea in summer indicated that the cold water zone extends from Geojedo to Pohang 1-2 d when the southwest wind strengthens. However, the following day when the wind weakens, the cold water area is limited to the Iduckseo coast (Gampo-Ulgi) below Guryongpo and leaves the coast. The cold water mass shown in this study appears as a tongue-shaped extension toward the offshore areas (Fig. 5, left). It is assumed that the size or area of the cold water mass is extremely sensitive to fluctuations in wind direction and stress.

In comparing the correlation between the wind stress at Gwangan station and the surface water temperature at the monitoring stations from April to September of 2016 and 2017, a difference in every station is observed. In general, however, the wind stress and water temperature are inversely correlated; hence, as the wind stress increases, the surface water temperature decreases. The inverse correlation coefficients were $(-0.30)-(-0.37)$ from Bukhang to Iduckseo stations and gradually decreased to $(-0.25)-0$ toward the north from the Guryongpo station. The time lag of water temperature with respect to wind is 7-8 $\mathrm{d}$ and exhibits the highest inverse correlation between 2 and $3 \mathrm{~d}$. This means that after the wind starts blowing along the coast, the water temperature is lowest within 2 to $3 \mathrm{~d}$ and decreases for approximately 7-8 d thereafter. However, these results are only based on the time difference correlation analysis between the two time series. In order to understand the relationship between the ocean water temperature and fluctuations of external influences (wind and air temperature) in various frequency domains, it is necessary to investigate the spectral correlation and dominant fluctuation periods of water temperature and external influences.

\section{Dominant fluctuation period of surface water temperature}

The dominant fluctuation period of water temperature in the southeast and east coasts is approximately $1,7,10,12,15,18$, and $23 \mathrm{~d}$ (Table 3 ). The inertia period (19-21 h) of these seas is less than $1 \mathrm{~d}$, and the probability of generating and propagating internal tidal waves with a daily period is extremely low (Baines, 1973). Therefore, the $1 \mathrm{~d}$ period may be a quasi-inertial period due to wind (with a higher frequency than the inertia period; Nam, 2006) or due to fluctuations in the solar radiation energy, such as air temperature (Choi et al., 2002). The difference among the vertical velocities of the water layer in coastal waters lowers the stratification stability and causes water layer mixing. Therefore, the fluctuation period and amplitude of surface water temperature because of wind stress acting on the seawater may vary with the inertia period or be more dependent on the stratification. In addition, these coasts are sea areas in which the seasonal thermocline is strongly formed by the distribution of various water masses by season and coastal cold water in summer. Therefore, the impacts of internal waves caused by a large change in vertical density (Baines, 1986), mixing due to wave instability, external weather factors, such as sea surface cooling and monsoons (Matsuyama, 1985), and nonlinear influence (Ippen \& Harleman, 1966; Friedrichs \& Aubrey, 1988) caused by water layer conditions and topography can combine; consequently, various water temperature fluctuation periods can occur. Dominant periods of wind and temperature fluctuations also appear in the water temperature fluctuations (Table 4). Water temperature fluctuations in the daily cycles, assumed to be caused by sea-land winds that reciprocate during daytime and nighttime, result in temperature variations. In these sea areas where sea conditions are dominated by wind and air temperatures affecting the tide and tidal currents, the water temperature may react or resonate due to a particular external force cycle, geography, topography, and depth of the sea area, resulting in water temperature variations for approximately 12 or $15 \mathrm{~d}$.

\section{Correlation between wind blowing and water temperature drop}

In the investigation of the correlation between surface water 
temperature and wind, the decrease in water temperature due to an increase in wind speed indicated various phase differences based on the fluctuation period (Fig. 8). Choo (2016) investigated the response of surface water temperature to wind around the waters of Ganjeolgot, located in the southeast coast of Korea. He reported that the surface water temperature had a phase difference of $12-18 \mathrm{~h}$ with respect to wind fluctuations over a period of 2-3 d; $24 \mathrm{~h}$ for $4 \mathrm{~d}$; $27-37 \mathrm{~h}$ for $4-5.4 \mathrm{~d}$; $36 \mathrm{~h}$ for $6 \mathrm{~d}$. This study is generally consistent with the result of the time series data analysis of the 17 points along the southeast and east coasts of Korea from April to September of 2016 and 2017. It was found that the drop in water temperature in the southeast coasts of Korea caused by the blowing of the south-southwest wind in spring and summer reacted within 0.5-3 d. Moreover, the decrease in water temperature occurring in response to the wind stress of the south-southwest wind in the spring and summer was generally large in the southeastern coastal area parallel to the direction of the southwestern seasonal wind. However, the correlation was relatively low at the stations in the south and east coasts because of differences in the wind directions and topographic shapes of these sea areas.

\section{Summary and Conclusion}

The phenomenon of cold water occurring at 17 monitoring stations along the southeast and east coasts of 2016-2017 was explained using the time series of surface water temperature, wind stress and air temperature, CTD survey data, interpretation of satellite image data, and spectrum analysis of time series data. From April to September (spring and summer), the southeast coast (Bukhang to Idukseo) showed a drop in water temperature every several days to one week, and the east coast (Hupo to Yeongok) showed a drop in water temperature every few days. The period and width of the drop in water temperature were longer and greater on the southeast coast than on the east coast. In the open sea, this drop in water temperature was not remarkable. The wind was from northwest to northeast in winter and autumn, and southwest to south-southwest in spring and summer, and the south-southwest wind was outstanding during the period when the water temperature decreased significantly.

Air temperature fluctuations were large in winter and autumn, so water temperature fluctuations were more sensitive to wind direction than air temperature. The sea area with large water temperature fluctuations was the east coast in April-June, and the southeast coast in July-September. When the southwest wind blew continuously, cold water areas were formed, but the opposite wind (northeast wind), the water temperature recovered or rose as if jumping. The wind (south-southwest wind) stress parallel to the southeast coast and water temperature were inversely correlated, and as the stress increased, the surface water temperature decreased. The inverse correlation coefficient was large at Bukhang to Idukseo, and gradually decreased from Guryongpo toward the northern coast. The cold water mass appeared from Geojedo to Pohang 1 to 2 days after the southwest wind became stronger. When the wind was weak, the cold water mass was reduced to the coast of Idukseo (Gampo-Woolgi) under Guryongpo and expanded toward the offshore area like a tongue, and the fluctuation was sensitive to the direction and magnitude of wind stress. In the vertical structure of water temperature when the cold water mass was developed, the isotherm was inclined toward the offshore area and the slope was very large. The strongest cold water was in mid-August, and from spring to summer, the center of the cold water area descended from the north of the east coast to the southeast coast. The center of cold water was formed in Toseong-Samcheok before midMay, and then spread to Gwangan and Bukhang, but from late May to mid-July, it spreaded from Guryongpo-Idukseo to $\mathrm{Hu}$ po-Jukbyeon-Samcheok. However, from August to September, cold water masses were distributed only in Bukhang-Idukseo and did not spread to the north.

The surface water temperature was dominant in periodic fluctuations around the $1 \mathrm{~d}$ and 7-21 d, and this period also appeared in wind speed and air temperature fluctuations. The daily fluctuation was estimated to be due to the air temperature change of the day and night and sea and land breeze. Other periods (7-21 d) may be generated during mixing due to internal wave and wave instability caused by seasonal changes in vertical density, and mixing by external weather factors such as sea surface cooling and monsoons. In addition, there is a possibility that fluctuations may have appeared depending on the non-linear effect caused by the combined action between the water layer condition and the topography of the sea area. Therefore, it is presumed that the fluctuations in wind and air temperature may have responded to or resonated with the water temperature due to the geography, topography, and depth of the sea area. In the wavelet spectrum analysis of water temperature and wind stress in spring and summer, the water temperature drop due to the increase in wind speed had a phase difference of $12 \mathrm{~h}$ in 2 $\mathrm{d}, 18 \mathrm{~h}$ in $3 \mathrm{~d}, 1.5 \mathrm{~d}$ in $4-8 \mathrm{~d}$, and $2-3 \mathrm{~d}$ in $8-24 \mathrm{~d}$ period. These correlations were large between Geojedo-Namhang (south sea 
area), Bukhang-Idukseo (southeast sea area), Guryongpo-Jukbyeon (central east sea area), and Samcheok-Toseong (north east sea area). The water temperature monitoring stations, which were highly correlated in all fluctuation periods were sea areas parallel to the southwest wind direction.

Until now, studies on cold water appearing on the coast of Korea have mainly focused on the characteristics of cold water masses appearing in the southeastern coast of Korea, Ulgi-Gampo, and the origin of their appearance. This study investigated the spatial and temporal behavior and fluctuations as well as the origin of cold water from 2016 to 2017 in the Southeast Sea to East Sea of Korea. In addition, by confirming with monitoring data that various water temperature reactions are occurring by sea area (depending on the topography and surrounding sea conditions), it was possible to suggest that not only the southeast coast of Korea but also the northern coast of the East Sea, where the coastal shape is monotonous, are sensitive to Ekman transport by monsoons. In the future, a more accurate prediction of sea conditions in the southeast and northern coasts of Korea will be made if the spatial and temporal behavior of the surface and bottom waters and the structure of the sea conditions for the upwelling and down-welling areas are reviewed with monitoring data of water temperature and seawater flow, simultaneously. Meanwhile, wavelet spectrum analysis in this study was used to show the relationship between wind stress at Gwangan station, located on the southeast coast of Korea, and SST at 17 coastal stations in the southeast and northern coasts of Korea. Therefore, in order to more clearly understand the relationship between the SST in the northern coast of the East Sea and the wind in the corresponding sea area, wavelet spectrum analysis using the wind data measured at the northern coast is considered to be necessary. If wavelet spectrum analysis using these data is carried out in the future, the dynamics of the emergence of cold water not only in the southeast coast of Korea, but also in the northern coast of the East Sea due to excellent winds will become clearer.

\section{Competing interests}

No potential conflict of interest relevant to this article was reported.

\section{Funding sources}

This research was a part of the project titled 'Research center for fishery resource management based on the information and communication technology' (2021), funded by the Ministry of
Oceans and Fisheries, Korea.

\section{Acknowledgements}

Not applicable.

\section{Availability of data and materials}

Upon reasonable request, the datasets of this study can be available from the corresponding author.

\section{Ethics approval and consent to participate}

This manuscript does not require IRB/IACUC approval because there are no human and animal participants.

\section{ORCID}

Hyo-Sang Choo

https://orcid.org/0000-0001-5214-7838

\section{References}

An HS. On the cold water mass around the southeast coast of Korean peninsula. J Oceanol Soc Korea. 1974;9:10-18.

Baines PG. Internal tides, internal waves and near-inertial motions. In: Mooers CNK, editor. Baroclinic processes on continental shelves. Washington, DC: American Geophysical Union; 1986. p. 19-31.

Baines PG. The generation of internal tides by flat-bump topography, Deep Sea Res. 1973;20:179-205.

Byun SK. Sea surface cold water near the southeastern coast of Korea: wind effect, J Oceanol Soc Korea. 1989;24:121-31.

Choi YH, Ro YJ, Jun HK. Variation of seawater temperature in the coastal waters off the Dangjin Power Plant, Asan Bay, Korea. Sea J Korean Soc Oceanogr. 2002;7:43-50.

Choo HS. Variation and structure of cold water around Ganjeol point off the southeast coast of Korea. J Korean Soc Mar Environ Saf. 2016;22:836-45

Friedrichs CT, Aubrey DG. Non-linear tidal distortion in shallow well-mixed estuaries: a synthesis. Estuar Coast Shelf Sci. 1988;27:521-45.

Grinsted A, Moore JC, Jevrejeva S. Application of the cross wavelet transform and wavelet coherence to geophysical time series. Nonlinear Process Geophys. 2004;11:561-6.

Hellerman S, Rosenstein M. Normal monthly wind stress over the world ocean with error estimates. J Phys Oceanogr. 1983;13:1093-104.

Ippen AT, Harleman DRF. Tidal dynamics in estuaries. In: Ippen AT, editor. Estuary and coastline hydrodynamics. New 
York, NY: McGraw-Hill; 1966. p. 493-545.

Kang YQ. Warming trend of coastal waters of Korea during recent 60 years (1936-1995). J Fish Sci Technol. 2000;3:1739.

Kim CH, Kim K. Characteristics and origin of the cold water mass along the east coast of Korea. J Oceanol Soc Korea. 1983;18:73-83.

Kim DS, Kim DH. Numerical simulation of upwelling appearance near the southeastern coast of Korea. J Korean Soc Mar Environ Saf. 2008;14:1-7.

Kim SW, Go WJ, Jang LH, Lim JW, Yamada K. Short-term variability of a summer cold water mass in the Southeast coast of Korea using satellite and shipboard data. In: Proceedings of the Korean Society of Marine Environment \& Safety, The 2008 Spring Conference; 2008; Mokpo, Korea.

Korea Meteorological Administration [KMA]. Monthly report of marine data 2016 [January to December]. Seoul: KMA; 2016.

Korea Meteorological Administration [KMA]. Monthly report of marine data 2017 [January to December]. Seoul: KMA; 2017.

Lee DK, Kwon JI, Hahn SB. The wind effect on the cold water formation near Gampo-Ulgi coast. J Korean Fish Soc. 1998;31:359-71.

Lee JC. Upwelling-response of the cold water off Haeundae in summer. J Korean Soc Oceanogr. 2011;16:206-11.

Lee JC. Variations of sea level and sea surface temperature associated with wind-induced upwelling in the southeast coast of Korea in summer. J Oceanol Soc Korea. 1983;18:149-60.

Lee JC, Na JY. Structure of upwelling off the southeast coast of Korea. J Oceanol Soc Korea. 1985;20:6-19.

Lee JC, Kim DH, Kim JC. Observations of coastal upwelling at Ulsan in summer 1997. J Oceanol Soc Korea. 2003;38:12234.

Matsuyama M. Internal tides in Uchiura Bay: subsurface temperature observations near the bay head. J Oceanogr Soc Jpn. 1985;41:135-44.

Nam SH. Near-inertial current variability off the east coast of Korea [Ph.D. dissertation]. Seoul, Korea: Seoul Natinal University; 2006. p. 14-21

NIFS [National Institute of Fisheries Science]. Distributions of sea water temperature around the coast of Korea in the year of 1997. Busan, Korea: NIFS; 1996. p. 277.

NIFS. Distributions of sea water temperature around the coast of Korea in the year of 1997. Busan, Korea: NIFS; 1998, p. 233.
NIFS. Oceanographic data and news. Busan, Korea: NIFS; $2016 \mathrm{a}$. No.: 4863, 4866, 4867, 4875.

NIFS. Oceanographic data and news. Busan, Korea: NIFS; 2017. No 4903, 4907-4909, 4917, 4927, 4931.

NIFS. Forecast, breaking news: NOAA-19 satellite image (Jul 29-30, 2016). Busan, Korea: NIFS; 2016b. https://www.nifs. go.kr/bbs?id=newfish

NIFS. Forecast, breaking news: weekly information of oceanic condition in East Sea of Korea, No.16-08-01. Busan, Korea: NIFS; 2016c. https://www.nifs.go.kr/bbs?id=wforecast

Seung YH. A dynamic consideration on the temperature distribution in the east coast of Korea in August. J Oceanol Soc Korea. 1974;9:52-8.

Seung YH. A numerical experiment of the effect of coastline geometry on the upwelling along the east coast of Korea. J Oceanol Soc Korea. 1984;19:24-30.

Suh YS. Oceanographic features around the Korean peninsula inferred from satellite remote sensing [Ph.D. dissertation]. Busan, Korea: Pukyong National University; 2001. p. 162-8.

Suh YS, Jang LH, Hwang JD. Temporal and spatial variations of the cold waters occurring in the Eastern coast of the Korean Peninsula in summer season. J Korean Fish Soc. 2001;34:435-44.

Thompson RORY. Low-pass filters to suppress inertial and tidal frequencies. J Phys Oceanogr . 1983;13:1077-83.

Walters RA, Heston C. Removing tidal-period variations from time-series data using low-pass digital filters. J Phys Oceanogr. 1982;12:112-5. 